\title{
Working Environment Effects on Peak Expiratory Flow Rate among Traditional Egyptian Bakers
}

\section{Sally Adel Hakim and Walid Salah El-Din}

Department of Community, Environmental and Occupational medicine, Faculty of Medicine, Ain Shams University

Received: October, $2018 \quad$ Accepted: December, 2018

\begin{abstract}
:
Background: Bakers face various common health problems at their work which may be aggravated when combined with improper awareness of ways of protection. Objective: The current study aimed at determining the most common symptoms encountered by bakers and to compare the peak expiratory flow rates of bakers with a control group. Method: The study included 71 bakers and 120 controls. The participants filled an interview questionnaire containing socio-demographic data as age, marital status, education, occupational background and questions about history of common diseases, body mass index was calculated, and peak expiratory flow rates were measured. Results: The mean expiratory flow rate of bakers was significantly lower than that of the control group. None of the workers reported receiving training to raise their awareness on the types of occupational disorders and methods of prevention. As regard respiratory symptoms, a significant difference was detected between groups regarding chest tightness $(\mathrm{P}=0.009)$ and sweating $(\mathrm{p}=0.03)$. Multiple logistic regression was done to identify factors associated with abnormal PEFR among bakers. After adjustment of relevant factors (age, BMI, job duration, working hours and workplace characteristics), it was found that exposure to heat in workplace was the independent factor affecting PEFR. Conclusion: The study concluded that bakery workers had various health problems related to the nature of their work and the work environment needed application of safety standards.
\end{abstract}

Keywords: bakery workers, health disorders among bakers, awareness of bakers, heat exposure in bakeries

Corresponding author: Sally Adel Hakim Email: drsallyhakim7@gmail.com

\section{Introduction:}

Flour is defined as complex organic dust containing cereals like wheat, rye, barley, oats, rice or corn or a combination of these, which have been processed by milling. ${ }^{1}$ Flour dust usually contains various components which play an important role in dough improvement, such as a variety of enzymes $(\alpha$-amylase, cellulase, malt enzymes, lipase), additives (baker's yeasts, egg powder, milk powder, sugar), flavorings, spices, chemical ingredients (preservatives, antioxidants, bleaching agents) but may also comprise of storagerelated contaminants, such as microbes or mites.

Epidemiological reports have showed that asthma, conjunctivitis, rhinitis and dermal reactions are the major health effects of flour dust exposure. ${ }^{2}$ From among these effects, baker's asthma is the most severe and frequent manifestation of occupational allergy. 3,4
No. 2

April 2019 
Baker's asthma results from immunological sensitization following allergic reactions to specific occupational airborne allergens. ${ }^{2}$

During the previous twenty years, several authors have studied the incidence of occupational asthma among bakers and showed incidence rates ranging from 0.334 to 2.46 cases per 1.000 person-years. ${ }^{5,6}$ The categories of agents implicated include flour that is the main cause of baker's allergy, contaminants of flour as storage mite or moulds and substances which are added during bread making process ( $\alpha$-amylase, baker's yeast, soy lecithin and others). Studies have shown that bakers had significantly lower forced expiratory indices than the control groups. $^{7-9}$ However, a study on the Egyptian population and from the aspect of occupational affecting factors and comparing those with normal to abnormal PEFR is needed to enrich the research field.

Moreover, occupationally exposed workers to flour dust were found to be more likely at risk of developing nasal cavity cancer. $^{10,11}$

It was also reported that exposure to flour dust can cause pathological abrasions of hard teeth tissues. ${ }^{12}$

A higher prevalence of occupational skin diseases has been reported among bakers than in the general population. ${ }^{13,14}$

In addition, bakeries have processes which produce high noise levels above the threshold limit values. ${ }^{15}$ Workplace noise can lead to irreversible hearing loss. ${ }^{16}$

Workers at bakeries can also be exposed to extreme heat which may result in heat stress. ${ }^{17}$ Heat stress can lead to heat stroke, heat cramps, heat exhaustion and heat rash. Heat can also result in increased probability of work accidents. ${ }^{18}$

Several risk factors among bakers predispose them to musculoskeletal disorders as repetitive movements, inappropriate posture and prolonged standing. ${ }^{19}$

It is crucial that workers have good knowledge of occupational health and safety measures to ensure effective and successful practices of occupational health services in the work. ${ }^{20}$

The current study aimed at determining the most common symptoms encountered by bakers and to compare the peak expiratory flow rates of bakers with a control group.

\section{Methods}

This is a cross sectional study to investigate the relationship between peak expiratory flow rate and some anthropometrical parameters (body weight and height). The study included 191 participants. A sample of 71 male bakers was taken from all traditional bakeries of regions of: Masr Gadida, Ard El Golf, Madinat Nasr, Abbassia, Nozha El Gadida, Wast El Balad, Shobra; a total of 37 bakeries, Cairo, Egypt. These bakeries served different social class areas and environmental working conditions were close in all bakeries. Other 120 control male participants were taken from neighborhood not exposed to flour dust and of the same age and socioeconomic group as the bakers. The bakers had at least 2 years of occupational exposure

Exclusion criteria included workers for less than 2 years in this field, those suffering from chronic respiratory conditions or facial disorders.

Anthropometric measurements in the form of weight and height were measured and body mass index calculated.

Peak expiratory flow rates were measured using the mini-Wright peak flow meter (PFM 20, OMRON). Then, the measured values were compared with the expected for age using peak expiratory flow rate (PEFR) reference values based on graphs in which the PEF (L/min) is plotted on $\mathrm{y}$ axis and age in years is plotted on $\mathrm{x}$-axis. 
Table 1: Comparison between bakers and non bakers as regards personal data:

\begin{tabular}{|c|c|c|c|c|c|c|}
\hline \multirow{2}{*}{\multicolumn{3}{|c|}{ Personal data }} & Baker & non Baker & \multirow{2}{*}{$\mathbf{t} / \mathbf{X}^{2}$} & \multirow{2}{*}{$P$ value } \\
\hline & & & Mean \pm SD/n (\%) & $\operatorname{Mean} \pm \operatorname{SD} / \mathrm{n}(\%)$ & & \\
\hline \multicolumn{3}{|l|}{ Age } & $35.10 \pm 8.83$ & $36.79 \pm 8.81$ & $1.283^{*}$ & 0.201 \\
\hline \multicolumn{3}{|c|}{ Body mass index } & $27.79 \pm 5.43$ & $26.82 \pm 4.67$ & $1.299 *$ & 0.195 \\
\hline \multicolumn{3}{|c|}{ Job duration } & $5.28 \pm 2.09$ & $5.56 \pm 2.05$ & $0.894 *$ & 0.373 \\
\hline \multicolumn{3}{|c|}{ Working hours per day } & $8.38 \pm 1.88$ & $7.88 \pm 1.72$ & $1.861^{*}$ & 0.064 \\
\hline \multicolumn{3}{|c|}{ Peak expiratory flow rate } & $529.4 \pm 61.12$ & $584.5 \pm 53.45$ & $6.527 *$ & 0.0001 \\
\hline \multirow{2}{*}{\multicolumn{2}{|c|}{ Current smoking }} & No & $35(49.3)$ & $74(61.7)$ & \multirow{2}{*}{$2.78 * *$} & \multirow{2}{*}{0.095} \\
\hline & & Yes & $36(50.7)$ & $46(38.3)$ & & \\
\hline \multicolumn{7}{|c|}{ Occupational exposures } \\
\hline \multicolumn{3}{|c|}{ Heat } & $48(67.6)$ & \multicolumn{2}{|c|}{$\begin{array}{l}58(48.3) 6.708 * * \\
\end{array}$} & 0.01 \\
\hline \multicolumn{3}{|c|}{ Dust } & $30(42.3)$ & \multicolumn{2}{|c|}{\begin{tabular}{|l|l|}
$37(30.8)$ & $2.55^{* * *}$ \\
\end{tabular}} & 0.110 \\
\hline \multicolumn{3}{|c|}{ Lack of ergonomics } & $57(80.3)$ & \multicolumn{2}{|c|}{$\begin{array}{ll}17(14.2) 82.15^{* * *} \\
\end{array}$} & 0.0001 \\
\hline \multicolumn{3}{|c|}{ Workplace aeration: good } & $28(39.4)$ & \multicolumn{2}{|c|}{$54(45) 0.564 * *$} & 0.453 \\
\hline \multirow[t]{3}{*}{ BMI } & Norma & & $22(35.2)$ & \multicolumn{2}{|c|}{\begin{tabular}{l|l|l|}
$55(45.8)$ & $1.36 * * *$ \\
\end{tabular}} & 0.286 \\
\hline & Overw & & $25(35.2)$ & \multicolumn{2}{|c|}{$40(33.3) 1.645^{* * *}$} & 0.199 \\
\hline & Obese & & $21(29.6)$ & \multicolumn{2}{|c|}{25 (20.8) $2.05 * * *$} & 0.151 \\
\hline
\end{tabular}

A line from age to cut the curves of height in men at $160 \mathrm{~cm}, 167 \mathrm{~cm}, 175 \mathrm{~cm}, 183$ $\mathrm{cm}, 190 \mathrm{~cm})$ and from it the corresponding $\mathrm{PEF}$ (L/min). In men, readings up to 100 $\mathrm{L} / \mathrm{min}$ lower than predicted are within normal limits (Adapted by Clement Clarke). The best of three readings was noted.

Participants also filled an interview questionnaire including: sociodemographic data as age, marital status, education, occupational background as job duration, working hours per day and questions about history of common diseases.

Statistical package and Statistical analysis: The collected data was revised, coded, tabulated and introduced to a PC using Statistical package for Social Science (IBM Corp. Released 2011. IBM SPSS Statistics for Windows, Version 20.0. Armonk, NY: IBM Corp). Student t test was used to compare a continuous variable between two study groups. Chi square, Fisher's exact and $\mathrm{z}$ test tests were used to examine the relationship between
Categorical variables. P-value $<0.05$ was considered statistically significant

\section{Ethical consideration}

The objectives of the study were explained to participants, and they were assured that the data would be kept confidential. Verbal consent was obtained from all participants in the study.

\section{Results}

Table (1) shows that there was no significant difference between bakers and non-bakers as regards personal data and job characteristics except for occupational exposures of heat ( $p$ value $=0.01)$ and lack of ergonomics ( $p$ value $=0.0001$ ). The mean expiratory flow rate of bakers was significantly lower than that of the control group. None of the workers reported receiving training to raise their awareness on the types of occupational hazards and methods of prevention.

Table (2) shows that a highly significant difference between groups was found as regard PEFR, with approximately $67 \%$ of bakers having low for age PEFR compared 
Table 2: Comparison between bakers and non bakers as regards some study variables:

\begin{tabular}{|c|c|c|c|c|}
\hline \multirow{2}{*}{$\begin{array}{c}\text { Study } \\
\text { population }\end{array}$} & \multicolumn{2}{|c|}{$\begin{array}{l}\text { Peak expiratory flow } \\
\text { rate }\end{array}$} & \multirow{2}{*}{$\mathbf{X}^{2}$} & \multirow{2}{*}{$\begin{array}{c}\mathbf{P} \\
\text { value }\end{array}$} \\
\hline & normal & $\begin{array}{c}\text { Below } \\
\text { normal }\end{array}$ & & \\
\hline \multirow{4}{*}{$\begin{array}{l}\text { Bakers } \\
\text { Non } \\
\text { Bakers }\end{array}$} & $23(32.4)$ & $48(67.6)$ & \multirow{2}{*}{39.6} & \multirow{2}{*}{$<0.001$} \\
\hline & $94(78.3)$ & $26(21.7)$ & & \\
\hline & \multicolumn{2}{|l|}{ Sneezing } & \multirow{4}{*}{3.37} & \multirow{4}{*}{0.06} \\
\hline & no & yes & & \\
\hline \multirow{2}{*}{$\begin{array}{l}\text { Bakers } \\
\text { Non } \\
\text { bakers }\end{array}$} & $43(60.6)$ & $28(39.4)$ & & \\
\hline & $88(73.3)$ & $32(26.7)$ & & \\
\hline \multirow{4}{*}{$\begin{array}{l}\text { Bakers } \\
\text { Non } \\
\text { bakers }\end{array}$} & \multicolumn{2}{|c|}{ Running nose } & \multirow{4}{*}{1.30} & \multirow{4}{*}{0.25} \\
\hline & no & yes & & \\
\hline & $44(62)$ & $27(38)$ & & \\
\hline & $84(70)$ & $36(30)$ & & \\
\hline \multirow{4}{*}{$\begin{array}{l}\text { Bakers } \\
\text { Non } \\
\text { bakers }\end{array}$} & \multicolumn{2}{|c|}{ Chest tightness } & \multirow{4}{*}{6.77} & \multirow{4}{*}{0.009} \\
\hline & no & yes & & \\
\hline & $37(52.1)$ & $34(47.9)$ & & \\
\hline & $85(70.8)$ & $35(29.2)$ & & \\
\hline \multirow{4}{*}{$\begin{array}{l}\text { Bakers } \\
\text { Non } \\
\text { bakers }\end{array}$} & Cough & & \multirow{4}{*}{3.33} & \multirow{4}{*}{0.068} \\
\hline & no & yes & & \\
\hline & $55(45.8)$ & $65(54.2)$ & & \\
\hline & $23(32.4)$ & $48(67.6)$ & & \\
\hline \multirow{4}{*}{$\begin{array}{l}\text { Bakers } \\
\text { Non } \\
\text { bakers }\end{array}$} & Sweating & & \multirow{4}{*}{4.30} & \multirow{4}{*}{0.03} \\
\hline & no & yes & & \\
\hline & $31(43.7)$ & $40(56.3)$ & & \\
\hline & $71(59.2)$ & $49(40.8)$ & & \\
\hline
\end{tabular}

to $22 \%$ only of non-bakers. As regards respiratory symptoms, a significant difference was detected between groups regarding chest tightness $(\mathrm{P}=0.009)$ and sweating $(\mathrm{p}=0.03)$, a near significant difference as regards sneezing $(\mathrm{p}=0.06)$ and cough $(\mathrm{p}=0.06)$, while non-significant difference regarding running nose.

Table (3): When comparing bakers with normal PEFR to those with abnormal Peak expiratory flow rate as regards personal and occupational history, no significant difference was detected.

Table (4): shows that a significant difference exists between bakers with normal and those with abnormal peak expiratory flow rate as regards heat exposureTable (5) shows the multiple logistic regression which was done to identify factors associated with abnormal PEFR among bakers. After adjustment of relevant factors (age, BMI, job duration, working hours and workplace characteristics), it was found that exposure to heat in workplace was the independent factor affecting PEFR (adjusted odds ratio $=5.78, \mathrm{CI}=1.38-24.15, \mathrm{P}<0.05)$.

\section{Discussion}

The present study included 71 bakers with mean age of 35 years and mean work duration of 5 years and mean working hours 8 hours/day. There were also 120 non bakers included with mean age of 36 years and mean job duration of 5 years and working hours of 7.8 hours/day. There was no significant difference between both groups as regards socio-demographic characteristics and body mass index. Regarding the mean expiratory flow rate of bakers, it was significantly lower than that of the control group. This finding is similar to that of another work. ${ }^{21,22}$ There was a significant difference between the 2 study groups in occupational exposures of heat and lack of ergonomics where the percentage of bakers reporting suffering from these two exposures was significantly higher than the non bakers. Bakery work is highly connected to work related musculoskeletal disorders because of long standing position, repetitive movements and also unsafe work conditions. $^{23,24}$

Moreover, approximately $70 \%$ of bakers in the current work reported exposure to heat, in another work $100 \%$ of bakers reported heat exposure and stated that workplace aeration was poor. ${ }^{25}$ Heat exposure was found to be an independent factor affecting peak expiratory flow rate by logistic regression. Hot environments are associated with lower lung functions as geographic factors including climate could have an effect on population respiratory

No. 2

April

2019 
Table 3: Comparison between bakers with normal and abnormal Peak expiratory flow rate as regard personal and occupational history

\begin{tabular}{|c|c|c|c|c|c|}
\hline \multirow{3}{*}{\multicolumn{2}{|c|}{ Personal and occupational data }} & \multicolumn{2}{|c|}{ Peak expiratory flow rate } & \multirow{3}{*}{$t / x^{2} / z$} & \multirow{3}{*}{$P$ value } \\
\hline & & Normal & Below normal & & \\
\hline & & Mean \pm SD & Mean \pm SD & & \\
\hline \multirow{4}{*}{\multicolumn{2}{|c|}{$\begin{array}{l}\text { Age } \\
\text { Job duration } \\
\text { Working hours per day } \\
\text { Body mass index }\end{array}$}} & $32.43 \pm 7.67$ & $36.37 \pm 9.13$ & $1.78^{*}$ & 0.07 \\
\hline & & $4.87 \pm 2.47$ & $5.48 \pm 1.88$ & $1.15^{*}$ & 0.25 \\
\hline & & $8.17 \pm 1.72$ & $8.48 \pm 1.96$ & $0.63 *$ & 0.52 \\
\hline & & $26.35 \pm 4.34$ & $28.47 \pm 5.79$ & $1.55^{*}$ & 0.12 \\
\hline \multicolumn{6}{|c|}{$\mathbf{N}(\%)$} \\
\hline \multirow{3}{*}{$\begin{array}{l}\text { Marital } \\
\text { status }\end{array}$} & Married & $14(60.9 \%)$ & $31(64.6 \%)$ & $0.092 * *$ & 0.761 \\
\hline & Divorced or widow & $4(17.4 \%)$ & $5(10.4 \%)$ & $0.683^{* *} *$ & 0.458 \\
\hline & Single & $5(21.7 \%)$ & $12(25 \%)$ & $0.092 * *$ & 0.763 \\
\hline \multirow[t]{6}{*}{ Education } & Illiterate & $3(13 \%)$ & $9(18.8 \%)$ & $0.361 * *$ & 0.729 \\
\hline & Read and write only & $4(17.4 \%)$ & $10(20.8 \%)$ & $0.116^{* *}$ & 0.733 \\
\hline & Finished primary & $7(30.4 \%)$ & $7(14.6 \%)$ & $2.46^{* *}$ & 0.116 \\
\hline & Finished preparatory & $6(26.1 \%)$ & $11(22.9 \%)$ & $0.08 * *$ & 0.770 \\
\hline & Finished secondary & $3(13 \%)$ & $8(16.7 \%)$ & $0.15 * *$ & 0.693 \\
\hline & University & $0(0 \%)$ & $3(6.3 \%)$ & $1.5 * *$ & 0.221 \\
\hline Smoking & $\begin{array}{l}\text { No } \\
\text { Yes }\end{array}$ & $\begin{array}{l}8(34.7 \%) \\
15(65.3 \%)\end{array}$ & $\begin{array}{l}27(56.2 \%) \\
21(43.8 \%)\end{array}$ & $2.87 * * *$ & 0.09 \\
\hline
\end{tabular}

*Student t test, $* * Z$ test, $* * *$ Chi squared test

health. ${ }^{26}$ Noise is also an occupational hazard at bakeries due to different activities as flour storage, oven, mixer and dough molder. ${ }^{27}$ Exposure to dust among bakers is an established occupational hazard such that bakers are exposed to flour dust at levels which put them at an excess risk of developing chronic respiratory diseases and has to be controlled. $^{28}$

However, it should be considered that the respiratory effects of flour dust exposure are affected by the dose and duration of exposure $^{29,30}$ and thus can be different from one working environment to the other. Therefore, it is not correct to extrapolate or refer the findings of studies done in different environments to the bakeries of another study. ${ }^{31,32}$ So, this may explain why our results may differ from others, moreover, it is known that the relation between dust exposure levels and respiratory effects is dose dependent ${ }^{33}$ and this was also revealed by other ${ }^{34}$ who found that highly exposed workers had significantly decreased lung functions than lightly exposed group of workers. Moreover, some investigators have reported normal pulmonary functions in workers exposed to flour dust. Kakooeil and Marioryad, 2005 found that there were no significant differences in the pulmonary function test results of the flour exposed group and the control group participants. ${ }^{35}$ The current study showed that bakers had significantly higher prevalence of respiratory symptoms than non bakers where a significant difference was detected between groups regarding chest tightness, sweating, while non-significant difference as regards running nose. This was similar to the findings of another study. ${ }^{36}$ Also Urom et al., 2015 reported higher prevalence of respiratory and non respiratory symptoms in workers chronically exposed to wheat dust. ${ }^{37}$ Only 
Table 4: Comparison between bakers with normal and abnormal Peak expiratory flow rate as regard workplace and work characteristics

\begin{tabular}{|c|c|c|c|c|c|}
\hline \multirow{2}{*}{\multicolumn{2}{|c|}{ Work characteristics }} & \multicolumn{2}{|c|}{ Peak Expiratory Flow Rate } & \multirow{4}{*}{$\begin{array}{l}\mathbf{x}^{2} / \text { Fisher } \\
0.23^{*}\end{array}$} & \multirow{4}{*}{$\begin{array}{c}\mathbf{P} \\
\text { Value } \\
0.633\end{array}$} \\
\hline & & \multirow{2}{*}{$\begin{array}{c}\text { Normal for age } \\
\mathbf{N}(\%) \\
13(302 \%)\end{array}$} & $\begin{array}{l}\text { Below } \\
\mathrm{N}(\%) \\
\end{array}$ & & \\
\hline \multirow[b]{2}{*}{$\begin{array}{l}\text { Work aeration as felt by } \\
\text { workers }\end{array}$} & & & & & \\
\hline & $\begin{array}{l}\text { No } \\
\text { Yes }\end{array}$ & $\begin{array}{l}13(30.2 \%) \\
10(35.7 \%) \\
\end{array}$ & $\begin{array}{l}30(69.8 \%) \\
18(64.3 \%)\end{array}$ & & \\
\hline \multirow{2}{*}{ Heat exposure } & No & $12(52.2 \%)$ & $11(47.8 \%)$ & \multirow[t]{2}{*}{$6.0^{*}$} & \multirow[t]{2}{*}{0.014} \\
\hline & Yes & $11(22.9 \%)$ & $37(77.1 \%)$ & & \\
\hline \multirow{2}{*}{ Dust exposure } & No & $6(42.9 \%)$ & $8(57.1 \%)$ & \multirow[t]{2}{*}{$\mathrm{FE}^{* *}$} & \multirow[t]{2}{*}{0.359} \\
\hline & Yes & $17(29.8 \%)$ & $40(70.2 \%)$ & & \\
\hline \multirow{2}{*}{$\begin{array}{l}\text { Noise as reported by } \\
\text { workers }\end{array}$} & No & $17(35.4 \%)$ & $31(64.6 \%)$ & \multirow[t]{2}{*}{0.61} & \multirow[t]{2}{*}{0.432} \\
\hline & Yes & $6(26.1 \%)$ & $17(73.9 \%)$ & & \\
\hline \multirow{2}{*}{ Awkward posture hazards } & No & $12(41.4 \%)$ & $17(58.6 \%)$ & \multirow[t]{2}{*}{$1.8^{*}$} & \multirow[t]{2}{*}{0.179} \\
\hline & Yes & $11(26.2 \%)$ & $31(73.8 \%)$ & & \\
\hline \multirow{5}{*}{$\begin{array}{l}\text { Workers perception of } \\
\text { work environment safety }\end{array}$} & No risk & $5(23.81 \%)$ & $16(76.19 \%)$ & \multirow[t]{5}{*}{$1.004^{*}$} & \multirow[t]{5}{*}{0.31} \\
\hline & Medium risk & $8(26.67 \%)$ & $22(73.33 \%)$ & & \\
\hline & High risk & $10(50 \%)$ & $10(50 \%)$ & & \\
\hline & Medium/high & $18(36.0 \%)$ & $32(64.0 \%)$ & & \\
\hline & & $\begin{array}{r}8(26.67 \%) \\
10(50 \%)\end{array}$ & $10(50 \%)$ & & \\
\hline \multirow{2}{*}{$\begin{array}{l}\text { Masks available at } \\
\text { workplace }\end{array}$} & No & $16(32.7 \%)$ & $33(67.3 \%)$ & \multirow[t]{2}{*}{$.005^{*}$} & \multirow[t]{2}{*}{0.955} \\
\hline & Yes & $7(31.8 \%)$ & $15(68.2 \%)$ & & \\
\hline \multirow{2}{*}{ Wear masks } & No & $20(33.9 \%)$ & $39(66.1 \%)$ & \multirow[t]{2}{*}{$\mathrm{FE}^{* *}$} & \multirow[t]{2}{*}{0.739} \\
\hline & Yes & $3(25 \%)$ & $9(75 \%)$ & & \\
\hline \multirow{2}{*}{$\begin{array}{l}\text { Periodic medical } \\
\text { examination (PME) }\end{array}$} & No & $20(34.5 \%)$ & $38(65.5 \%)$ & \multirow[t]{2}{*}{ FE** } & \multirow[t]{2}{*}{0.526} \\
\hline & Yes & $3(23.1 \%)$ & $10(76.9 \%)$ & & \\
\hline
\end{tabular}

*Chi squared test, ** Fisher Exact

$40 \%$ of the current study participants considered their workplace aeration as good so this may reflect the unhygienic working environment they are encountering and hence exposure to dust concentrations which may affect their respiratory function. The current study also revealed that none of the workers received pre-employment training on the types of occupational exposures and how to protect themselves and first aid measures similar to another work. ${ }^{38}$

When comparing bakers with normal PEFR to those with abnormal Peak expiratory flow rate as regards personal and occupational history of job duration (years) and working hours per day, no significant difference was detected. Heat exposure was the only factor among working characteristics which was of significant association such that the percentage of those with abnormal PEFR experiencing heat exposure at work was significantly higher than the percentage of bakers with normal PEFR reporting heat exposure. This was further confirmed by logistic regression analysis where exposure to heat was the only independent factor affecting PEFR among bakers (table 5). $\mathrm{CDC}$ and NIOSH reported that workers who are encountering extreme heat at workplaces and are working in hot environments are at risk of heat stress resulting in skin disorders and allergies. 
Table 5: Logistic Regression to study independent factors affecting PEFR among bakers

\begin{tabular}{|l|r|r|r|r|}
\hline \multirow{2}{*}{ variables } & Adjusted & \multicolumn{1}{|c|}{ P } & \multicolumn{2}{|c|}{ 95\% CI* for } \\
\cline { 3 - 5 } & Odds Ratio & value & Lower & Upper \\
\hline Age & 1.087 & 0.133 & 0.975 & 1.212 \\
\hline Job & 1.047 & 0.832 & 0.687 & 1.593 \\
\hline Working & 1.090 & 0.630 & 0.767 & 1.551 \\
\hline BMI & 1.119 & 0.068 & 0.992 & 1.262 \\
\hline Smoking & 2.411 & 0.094 & 0.860 & 6.754 \\
\hline Wear & 1.874 & 0.489 & 0.316 & 11.105 \\
\hline Awkward & .911 & 0.894 & 0.232 & 3.577 \\
\hline Good & 1.045 & 0.953 & 0.246 & 4.432 \\
\hline Have PME & 2.831 & 0.277 & 0.434 & 18.452 \\
\hline Exposure to & 5.780 & 0.016 & 1.383 & 24.156 \\
\hline Exposure to & 1.235 & 0.760 & 0.319 & 4.789 \\
\hline Exposure to & 2.327 & 0.266 & 0.526 & 10.291 \\
\hline
\end{tabular}

Moreover, inadequate ventilation inside traditional bakeries can predispose to skin disorders and allergies. ${ }^{39}$ Heat exposure is an established hazard in bakeries as was shown in a study among workers in bakeries of Assiut city where the average value of heat stress exceeded the recommended limit value. ${ }^{40}$ The results of regression analysis in the current work are similar to those of another study where higher mean values of ambient temperature were associated with decreased lung function in cohort studies. This study also stated that the mechanism underlying this association between affected lung function and warmer ambient temperature is uncertain. $^{41}$ The relation between temperature and PEFR has been investigated in the study by Pedersen et al., 1993 where higher temperatures were found to be associated with reduced readings. $^{42}$

The current study showed that 12 bakers (17\%) reported wearing personal protective devices namely masks, while another work showed that all bakery workers didn't use personal protective measures. ${ }^{25}$ Another study found that $60 \%$ of bakers wore face masks. ${ }^{43}$ Regarding the most commonly used type of personal protective used by bakers, this study found that it was masks while another study reported that aprons were the most commonly used personal protective equipment followed by gloves then ear plugs. ${ }^{44}$ It can be concluded from these results that workers lacked awareness about safety measures to avoid possible resulting health problems and injury from workplace exposures.

The finding that the mean expiratory flow rate of bakers was significantly lower than that of the non exposed group is similar to that of another work which also demonstrated the significantly lower respiratory functions and higher prevalence of respiratory symptoms among exposed workers than controls. ${ }^{45}$ Similarly, in other studies, it was found that all respiratory and allergic symptoms had a higher prevalence among bakers in comparison to the control group. ${ }^{46,47}$

From the factors studied to find out whether it is an independent factor affecting peak expiratory flow rate was aeration of the workplace as it is known that the level of exposure affects the PEFR which in turn will be reflected on the lung function and affecting the degree of airflow obstruction and reduction in the peak expiratory flow rate. Good aeration of the workplace affects the level of exposure and consequently lung function (48). In the current work, no statistically significant association was found between workplace aeration and PEFR. Body mass index and age were not factors significantly affecting peak expiratory flow rate by logistic regression, this is also similar to the study Atena et al., 2015 where age and body mass index were not significantly associated with an effect on respiratory function. ${ }^{49}$

\section{Conclusion}


Bakery workers had various health problems related to the nature of their work and the work environment so application of safety standards is needed. Raising their awareness also by providing training programs may help. Occupational exposures of heat, noise, dust exposure and lack of ergonomics among bakers have to be targeted by occupational health and safety professionals through preventive strategies.

Study limitations: This work used a questionnaire which included some variables that depend on history which may lead to recall bias. Also, we used only PEFR.

\section{Conflict of interest: none.}

Acknowledgement: The authors would like to deliver special thanks to the workers who participated in the study and their supervisors who gave us this opportunity.

\section{References:}

1. Karpinski EA. Exposure to inhalable flour dust in Canadian flour mills. Appl Occup Environ Hyg. 2003;18:1022-1030.

2. Agata Stobnicka and Rafał L. Górny. Exposure to flour dust in the occupational environment Int J Occup Saf Ergon. 2015; 21(3): 241-249.

3. Page EH, Dowell CH, Mueller CA, Biagini RE, Heederik D. Exposure to flour dust and sensitization among bakery employees. Am J Ind Med. 2010; 53(12):1225-1232.

4. Skjold T, Dahl R, Juhl B, Sigsgaard T. The incidence of respiratory symptoms and sensitisation in baker apprentices. Eur Respir J. 2008;32:452-459.

5. Ameille J, Pauli G, Calastreng-Crinquand A, Vervloet D, Iwatsubo Y, Popin E, BayeuxDunglas MC, Kopferschmitt-Kubler MC. Reported incidence of occupational asthma in France, 1996-99: the ONAP programme. Occupational and environmental medicine. 2003, 60 (2): 136-141.

The Egyptian Journal of Community Medicine
6. Leira HL, Bratt U, Slastad S: Notified cases of occupational asthma in Norway: exposure and consequences for health and income. American journal of industrial medicine. 2005, 48 (5): 359-364.

7. AlaEldin HA, Ilham EB, Tarig HM. Effects of exposure to flour dust on respiratory symptoms and lung function of bakery workers: a case control study. Sudanese Journal of Public Health 2009; 4 (1): 210- 213. 8. Mohammadien HA., Hussein $\mathrm{M} \mathrm{T}$, ElSokkary RT. Effects of exposure to flour dust on respiratory symptoms and pulmonary function of mill workers. Egyptian Journal of Chest Diseases and Tuberculosis 2013; 62: 745-753.

9. El-Helaly ME, El-Bialy AA. Skin prick tests and dose response relationship between pulmonary function tests and chronic exposure to flour in baking industry. Zagazig J Occup Health Safety 2010; 3(1): 9-19.

10. American Cancer Society. What are the risk factors for nasal cavity and paranasal sinus cancers? 2017. Available at: http://cancer.org/cancer/nasal-cavity-andparanasal-sinus-cancer/risk-factors.html. (last accessed on October 2018)

11. Canadian Cancer Society. Nasal cavity and paranasal sinus cancer. 2018. Available at: www.cancer.ca/en/cancer-information/cancertype/nasal-paranasal/risks/?region=on. (last accessed on October 2018)

12. Bachanek T, Pawłowicz A, Tarczydło B, Chalas R. Evaluation of dental health in mill workers. Part I. The state of dentition. Ann Agric Environ Med. 2001; 8 (1):103-5.

13. Arrandale V, Meijster T, Pronk A, Doekes G, Redlich CA, Holness DL and Heederick D. Skin symptoms in bakery and auto body shop workers: associations with exposure and respiratory symptoms. Int Arch Occup Environ Health 2013; 86(2): 167-75

14. McCullagh M.C., Raymond D., Kerr M.J. and Lusk S.L. Prevalence of hearing loss and accuracy of self-report among factory workers. Noise Health 2011; 13, 340-7.

15. Health and Safety Executive. A Baker's dozen. Thirteen essentials for health and safety in bakeries.2011. Available Online from: URL:http://books.hse.gov.uk/hse/public/hom e.jsf (Time of last access) 
16. Svagr J.J., Berkowitz D.E. and Stellman J.M. Health effects and Disease patterns. ILO Encyclopedia of Occupational Health and Safety. 2011. Available online from: URL:http://www.ilo.org/oshenc/part-

$\mathrm{x} /$ foodindustry/ overview-and-healtheffects/item/858-healtheffects-and-diseasepatterns (last accessed on September 2018) 17. Occupational Safety and Health Administration (OSHA). Protecting workers from heat stress. 2014. Available online at: www.osha.gov, 2014. (last accessed on September 2018)

18. Page E.H., Dowell C.H., Mueller C.A. and Biagini R.E. Evaluation of sensitization and exposure to flour dust, spices, and other ingredients among poultry breading workers. (Centers for Disease Control and Prevention \& National Institute for Occupational Safety and Health. 2010. Available online at: http://www.cdc.gov/niosh/hhe/reports/pdfs/. (last accessed on October 2018)

19. Beheshti M.H. Evaluating the potential risk of musculoskeletal disorders among bakers according to LUBA and ACGIH-HAL indices. JOHE 2014; 3(2): 72-80.

20. Abdulsalam S.T., Abdus-Salam I.A. and Arinde J.T. Occupational health Works in a flour mill in Ilorin, North Central, Nigeria. International Journal of Research and Reniem (IJRR) 2015. Available online at: www.gkpublication.in. (last accessed on October 2018)

21. Adekunle IM , Oluseyi AO. Ergonomic Consideration of the effect of flour dust on peak expiratory flow rate of bakers in Abeokuta, Ogun State. Safety Engineering Series 2017; 12(1): 19-24.

22. Ige OM, Awoyemi, OB. Respiratory symptoms and ventilatory function of the bakery workers in Ibadan, Nigeria, West Africa. Journal of Medical 2002; 21(4): 316 318.

23. The National Health and Safety (NHS): Urgent and Emergency Care Review: Progress and implementation plan. 2014. (Available online at: https://www. england.nhs.uk/wpcontent/uploads/2014/12/item8-board1214.pdf, 2014). (last accessed on September 2018)

24. Mortazavi M.M., Ebrahemzadih M., Tajvar A. and Giahi O. Survey of prevalence and risk factors associated with upper extremity musculoskeletal disorders by repetitive job activities methods in baker of Iran. Scientific research 2014. (Available online at: http:// www.scirp.org/journal/health). (last accessed on August 2018)

25. Doaa M.A., Nagah M.A., Heba M.S. Common health problems and safety measures among workers in traditional bakeries at Giza governorate. Med J. Cairo Univ 2017; 85(3): 993-1001.

26. Joseph M.C., Lawrence J.A., John M., Garry R.C. The relationship of lung function with ambient temperature. PLoS one 2018.

27. Ibrahium I.B., Aremus A.S., Ajao K.R. and Ojelabi A.T.: Evaluation of noise pollution and effects on workers during wheat processing. J. Appl. Sci. Environ. Manage 2014; 18 (4). 599601.

28. Jorunn K., Bjorg E.H., Trond R., Wijnand E., Magne B. and Torgeir S. Bakers' exposure to flour dust. Journal of Occupational and Environmental Hygiene 2017; 14(2): 81-91.

29. Brisman J, Lillienberg L, Jarvholm B. Exposure response relations for self reported asthma and rhinitis in bakers. Occupation and Environmental medicine (2000); ; 57:335- 40.

30. Meo SA. Dose responses of years of exposure on lung function in flour mill workers. Journal of occupation health (2006); 46:187-91.

31. Bulat P, Myny K, Braeckman L. Exposure to inhalable dust, wheat flour and alphaamylase allergens in industrial and traditional bakeries. Annal Occupational Hygiene 2004; 48:57-63.

32. Elms J, Beckett P, Griffin P. Job categories and their effects on exposure to fungal alphaamylase and inhalable dust in the UK baking industry. American Industrial Hygienic Association Journal 2003; 64: 467- 71.

33. Massin N, Bohadana AB, Wild P, KoloppSarda MN,Toamain JP. Airway responsiveness to methacholine, respiratory symptoms, and dust exposure levels in grain and flour mill workers in eastern France, Am. J. Ind. Med. 27 (1995) 859-869.

34. Chen P. The effect of grain dust on nonspecific bronchial hyperreactivity, Zhonghua Jie He He Hu Xi Za Zhi 1992; 15 (1) 28-30. 
35. Kakooei H., Marioryad H. Exposure to inhalable flour dust and respiratory symptoms of workers in a flour mill in Iran. Iran. J. Environ. Health Sci. Eng. 2005; 2 (1) 50-55. 36. Yousef M., Seyedtaghi M., Anees A., Syavash E.N. and Jamshid Y. Health-risk assessment of workers exposed to flour dust: A cross-sectional study of random samples of bakeries workers. Atmospheric Pollution Research 2014; 5 (1): 113-118.

37. Urom S.E., Osim E.E., Antai A.B., Aribo E.O. and Ofutet E.O. Prevalence of respiratory and non-respiratory symptoms among workers chronically exposed to wheat flour dust and other possible occupational hazard in flour mill industry, Calabar, Nigeria. IOSR Journal of Dental and Medical Sciences 2015; 36-39. Available online at: www.iosrjournals.org, 2015. (last accessed on September 2018)

38. Yossif H.A. and Abd Elaal E.M. Occupational hazards: Prevention of health problems among bakery workers in Benha City. Journal of American science 2012; 8 (3): 99-108. Available online at: http://www.americanscience.org). (last accessed on October 2018)

39. Centers for Disease Control and Prevention \& National Institute for Occupational Safety and Health. Page, E.H., Dowell, C.H., Mueller, C.A., \& Biagini, R.E.: Evaluation of sensitization and exposure to flour dust, spices, and other ingredients among poultry breading workers. Available online at: http://www.cdc.gov/niosh/hhe/reports/pdfs/ 2009-0131-3171.pdf, 2010). (last accessed on October 2018)

40. Rabeiy R. Evaluation of indoor heat stress on workers of bakeries at Assiut City, Egypt. International Journal of Environmental Science and Technology 2018; 10.1007/s13762-0181839-z.

41. Collaco JM, Appel LJ, McGready J, Cutting GR. The relationship of lung function with ambient temperature. PLoS ONE 2018; 13(1): e0191409. https://doi.org/10.1371/journal.pone.0191409. (last accessed on September 2018)
42. Pedersen OF, Miller MR, Sigsgaard T, Tidley M, Harding RM. Portable peak expiratory flow meters: physical characteristics, influence of temperature, altitude and humidity. Eur Respir J 1994; 7: 991-997.

43. Joshua IA, Abubakar I, Gobir AA, Nmadu AG, Igboanusi CC, Onoja-Alexander MO, Adiri F, Bot TC, I-Joshua W, Shehu AU. Knowledge of occupational hazards and use of preventive measures among bakery workers in Kaduna North Local Government Area, Kaduna State, Nigeria. Arch Med Surg 2017; 2(2):78-83.

44. Emmanuel A.N. and Onyia Sussan A.U. Assessment of baking industries in a developing country: The common hazards, health challenges, control measures and association to asthma. ISCA 2014. Available online at: www.isca.in, www.isca.me, 2014. (last accessed on October 2018)

45. D. Patouchas, G. Efremidis, K. Karkoulias, N. Zoumbos, P. Goumas, K. Spiropoulos. Lung function measurements in traditional bakers. Acta Biomed 2008; 79: 197-203

46. Ayman E.F. and Mahmoud E. Pulmonary function impairment and airway allergy among workers in traditional bakeries. Int $\mathbf{J}$ Occup Med Environ Health 2013; 26(2): 214-219.

47. Ijadunola K.T., Erhabor G.E., Onayade A.A., Ijandunola M.Y., Fatuse A.O., Asuzu M.C. Pulmonary functions of wheat flour mill workers and controls in Ibadan, Nigeria. American Journal of Industrial Medicine 2005; 48(4): 308.

48. Inem, V, Onubeze, DPM and Osuji CU. Toluene diisocyanate-linked occupational airflow obstruction and peak expiratory flow rate patterns among form workers", Africa journal of respiratory medicine 2010;12-16.

49. Atena R., Elnaz R., Mehdi A., NargesG.Z. and Somayeh F.D. Respiratory effects of exposure to flour dust: A case study among workers of flour production factories in Arak. Journal of Paramedical Sciences (JPS) 2015; 6(3): 79-84. 